\title{
Corporate Board Interlocks and New Product Introductions
}

Firms' boards of directors affect many strategic outcomes. Yet the impact of boards on new products, a key organizational adaptation mechanism, has been overlooked. Addressing this gap, the authors consider the effect of the firm's board interlock centrality, the extent to which board members are connected to boards of other firms, on its new product introductions. They propose that board interlock centrality provides firms access to market intelligence, creating opportunities to introduce incremental new products. Applying the motivation-opportunity-ability theory, the authors propose that two aspects of board leadership moderate this relationship: internal (vs. external) leadership and marketing leadership. They test the hypotheses using a panel of publicly listed U.S. consumer packaged goods firms, in which most new products are incremental innovations. As hypothesized, board interlock centrality increases new product introductions. This effect is stronger when firms have high internal leadership, internal marketing leadership, and a marketing CEO; it is weaker with high intra-industry external leadership. The findings highlight the unexpected role of board interlocks on innovation outcomes and advance the literature on marketing leadership, board interlocks, and social networks.

Keywords: board interlocks, corporate governance, networks, incremental innovations, new product introductions

Online Supplement. http://dx.doi.org/10.1509/jm.16.0120

n many industries, including consumer packaged goods $(\mathrm{CPG})$, new products are predominantly incremental in nature (Cao and Sorescu 2013; Wies and Moorman 2015). Such incremental innovations "involve relatively minor changes in technology and provide relatively low incremental customer benefits per dollar" (Chandy and Tellis 1998, p. 476). In view of their importance, prior research has examined the drivers and effects of incremental product introductions (Banbury and Mitchell 1995; Cao and Sorescu 2013; Olsen, Slotegraaf, and Chandukala 2014; Sorescu and Spanjol 2008; Steenkamp and Gielens 2003; Ter Braak, Dekimpe, and Geyskens 2013; Wies and Moorman 2015). We extend this literature by identifying a novel, hitherto overlooked driver of incremental new products: the firm's position in board interlock networks.

We build on recent developments in the marketing literature on the top-down influences of a firm's leadership on strategy and outcomes (e.g., Feng, Morgan, and Rego 2015; Germann,

Raji Srinivasan is Sam Barshop Centennial Professor of Marketing Administration, Red McCombs School of Business, University of Texas at Austin (email: raji.srinivasan @mccombs.utexas.edu). Stefan Wuyts is Professor of Marketing, Koç University (email: swuyts@ku.edu.tr). Girish Mallapragada is Assistant Professor of Marketing, Kelley School of Business, Indiana University (email: gmallapr@indiana.edu). The authors contributed equally and are listed in a random order. The authors thank Sandeep Arora, Rajesh Chandy, Gary L. Lilien, Vijay Mahajan, Christine Moorman, Francisco Polidoro, Raghunath Rao, Lisa Scheer, Raj Grewal, Rebecca Slotegraaf, and Jim Westphal for feedback on previous versions of the article and David Chandler, Jackie Pruitt, James Tang, and Shobhit Khandelwal for their help with the data collection. Rajkumar Venkatesan served as area editor for this article.

(c) 2018, American Marketing Association

ISSN: 0022-2429 (print)

1547-7185 (electronic)
Ebbes, and Grewal 2015). We examine the influence of the firm's board of directors and its ties with other firms, through board interlocks, on incremental new product introductions ("new product introductions" hereinafter). All publicly listed U.S. firms are required, by law, to appoint a board of directors consisting of at least three people to assess and direct the firm's strategy and to gain market intelligence and learn about best business practices (Lorsch and MacIver 1989; Mariolis and Jones 1982). Frequently, the directors on a firm's board are also members of boards of other firms, creating connections between the firm's board and other firms' boards, referred to as "board interlocks." For example, Ian Cook, a current board member at PepsiCo Inc., is also a member of the board at ColgatePalmolive Company. We propose that interlocks between a firm's board of directors and other firms' boards of directors influence its new product introductions.

Studies in the sociology, economics, and management literatures have identified board interlocks as a key source of market intelligence (e.g., Lang and Lockhart 1990; Useem 1984; Westphal and Fredrickson 2001). In the marketing literature, market intelligence has been extensively studied as a broad construct that captures "exogenous market factors (e.g., competition, regulation) that affect customer needs and preferences and current as well as future needs of customers" (e.g., Kohli and Jaworski 1990, p. 3). This conceptualization is consistent with Useem's (1984) interpretation of board interlocks as scanners of the business environment. Examples of changes in the business environment relevant to new product introductions include market trends, evolution of customer preferences, and changes in the regulatory environment. Firms in more central positions in board interlock networks (i.e., firms

Journal of Marketing

Vol. 82 (January 2018), 132-148 DOI: $10.1509 / j m .16 .0120$ 
with high board interlock centrality) have superior access to market intelligence, which is useful in identifying opportunities for organizational adaptation (Mizruchi 1996).

New products introduced on the basis of market intelligence do not usually involve "substantially different technology," nor do they offer "substantially greater customer benefits per dollar" relative to existing products (i.e., they are incremental innovations; Chandy and Tellis 1998, p. 476). We propose that the firm's board interlock centrality will provide it opportunities to increase such new product introductions.

Firms differ in the extent to which they seize these opportunities (Rindfleisch and Moorman 2001). Applying the motivation-opportunity-ability (MOA) theoretical framework (e.g., Tuggle et al. 2010; Wang, Gupta, and Grewal 2017), we propose that the positive effect of the firm's board interlock centrality on new product introductions will be stronger when its senior managers are motivated and able to translate the acquired market intelligence into new products.

We build a contingency model and specify moderation effects of the firm's board leadership characteristics on the effect of its board interlock centrality on its new product introductions. We draw on research on corporate governance (e.g., Hambrick 2007; Lant, Milliken, and Batra 1992) and marketing leadership (e.g., Feng, Morgan, and Rego 2015; Germann, Ebbes, and Grewal 2015) to propose that the effect of the firm's board interlock centrality on new product introductions is contingent on its internal (vs. external) leadership and marketing leadership on its board. We expect that these two aspects of leadership on the firm's board will affect the extent to which market intelligence is identified, shared, and acted on by its managers to develop new products. While there is a growing recognition that firms' strategic behaviors are guided by top-down influences from its board of directors, top management team, and chief executive officer (CEO) (Germann, Ebbes, and Grewal 2015; Rao, Chandy, and Prabhu 2008; Yadav, Prabhu, and Chandy 2007), little is known about top-down influences on innovations (cf. Bantel and Jackson 1989).

This study's findings make several theoretical contributions. First, we contribute to the literature on innovations by showing the top-down influence of board interlock networks on new product introductions, an issue that has been overlooked in the marketing literature. Second, we argue and show that aspects of board leadership, including internal (vs. external) leadership, the presence of marketing executives, and a CEO with a marketing background moderate the effect of board interlock centrality on innovation. Our findings on the effects of marketing leadership on the board provide a novel extension to the literature on the influence of marketing leadership on firm outcomes. Third, we contribute to the literature on board interlocks by examining their impact on new product introductions, a key adaptation mechanism that has not been examined in the literature. Fourth, the insight that a firm's senior leadership profile moderates the effect of its position in the board interlock network on new product introductions extends the social network literature. We disentangle the effects of an actor's network position (which provide an opportunity to obtain outputs) from his or her behaviors (which are driven by motivation and ability).

The study's findings also generate actionable insights for managers. Incremental new products are critical to address changes in consumer tastes, prevent competitive onslaught, and achieve revenue and profit growth. As such, in the many industries in which technological breakthroughs are not a key source of innovations, incremental new products help firms build competitive positions and ensure stability in performance. This study's findings also inform C-suite executives on how corporate governance decisions (i.e., appointments to firms' boards) influence innovation outputs.

To test our hypotheses, we needed an industry in which changes in consumer tastes and market trends (rather than changes in technology) drive incremental product introductions. The CPG industry is one such industry. We selected food and beverage firms between 1997 and 2012 as the empirical context for hypothesis testing. We obtained data from secondary sources on publicly listed food and beverage firms (required to report board composition), resulting in 231 firm-year observations for 30 firms. ${ }^{1}$

We measure the firm's board interlock centrality by its eigenvector centrality (EVC) in the board interlock network, which captures the connectivity of the focal firm based on both its direct and indirect connections to other well-connected firms in the board interlock network (Tuggle et al. 2010; Wang, Gupta, and Grewal 2017). We measure the firm's new product introductions by the annual count of new product introductions. We estimate a negative binomial regression model of new product introductions, correcting for both serial correlation and heteroscedasticity.

The findings-which are robust to alternative model specifications, endogeneity corrections, and alternative estimatorsindicate that the higher the firm's centrality in the board interlock network, the higher its new product introductions. This positive effect is stronger when the firm has a board with high internal board leadership, internal marketing leadership, and a marketing CEO. The effect is weaker when the firm has higher intraindustry external (i.e., from the same industry) leadership on the board.

The remainder of the article is organized as follows. First, we develop main and moderation hypotheses relating the firm's board interlock centrality to its new product introductions. Following that, we describe the data and method that we use to test the hypotheses and report the results. We conclude with a discussion of the study's contributions to theory and managerial practice, discuss its limitations, and identify opportunities for further research.

\section{Theory}

\section{Corporate Board Interlocks}

The firm's board of directors, which serves as its ultimate decision-making authority and safeguards shareholders' interests, is elected by its shareholders (Haynes and Hillman 2010). Directors on the firm's board have full access to its officers, employees, books, and records to enable them to effectively fulfill their oversight roles. The directors' advice to the firm's senior management is influenced by their experience and

${ }^{1}$ In a robustness analysis, we also included U.S. personal products firms, resulting in a sample of 280 firm-years. 
knowledge accumulated through their ties to directors of other firms (Mizruchi 1996). The network created by directors' ties to the business community outside the firm (as directors on the board of one firm also serve on the boards of other firms) is called the board interlock network (Mills 1956).

Firms' board interlocks affect various behaviors and have been extensively studied in the sociology, economics, and management literature streams (Mizruchi 1996). Scholars have examined the role of board interlocks in shaping social ties among firms (Mariolis and Jones 1982), reducing competition (Nguyen 2012), influencing decision making (Carpenter and Westphal 2001), acquiring information (Haunschild and Beckman 1998), scanning the environment (Useem 1984), and diffusing administrative innovations (Beckman and Haunschild 2002).

Board interlocks as conduits of market intelligence. The firm's senior executives develop firm strategy under the guidance of the board of directors (Palmer, Jennings, and Zhou 1993). Mizruchi (1996, p. 284) observed that "the emphasis [in the board interlock literature] has moved increasingly toward their value as a communication mechanism rather than as a mechanism of control." Because senior executives who serve on other firms' boards are privy to market intelligence (Haunschild 1993; Mariolis and Jones 1982), board interlocks are crucial channels for transfer of market intelligence across firms (e.g., Lang and Lockhart 1990; Useem 1984). This transferred market intelligence then influences the firm's strategy as senior managers discuss and formulate strategy at board meetings.

Senior executives appear to consider board interlocks an important source of market intelligence regarding consumers and competitors. Using semistructured interviews of CEOs at Fortune 100 firms, Beckman and Haunschild (2002, p. 97) report that the "tacit information that board members bring to the table" is relevant for firms' decision making. Haunschild and Beckman (1998, p. 817) note that board interlocks are influential because they are "inexpensive, trustworthy, credible information sources" that provide vivid, firsthand market intelligence based on directors' personal experiences, expressed through case exemplars rather than as abstract generalizations.

To further validate the notion that board interlocks are conduits for market intelligence and guide decision making, we contacted two sets of domain experts: (1) senior academic experts on top management teams and (2) members of boards of publicly listed firms. We asked the six academic experts to rate the extent to which they consider board interlocks a source of market intelligence. The mean rating of the academic experts, on a scale of 1-7, where 1 represents strong disagreement and 7 represents strong agreement, was 6.30. We also contacted eight board members at publicly listed firms in the United States and India, whose mean rating, on the same scale, was 6.25. As one of the respondents, a CEO at a web analytics firm, noted,

Corporate board interlocks can indeed be an effective source for passive market intelligence above and beyond traditional forms of intelligence gathering. I have personally witnessed several instances where we were able to make great progress by piggy-backing on the broader knowledge base from the extended reach into industry insights available to us as a direct result of our associations with other corporate boards. Pros outweigh the cons, by an order of magnitude.
We note that our focus on new product introductions represents a novel departure from prior work on board interlocks, which has overlooked innovation outcomes (see reviews by Lamb and Roundy [2016] and Mizruchi [1996]), with the exception of one study relating board interlocks to researchand-development (R\&D) expenditures (Dalziel, Gentry, and Bowerman 2011). We next discuss the effects of board interlocks on new product introductions.

Board interlocks and (incremental) new products. We propose that because board interlocks are important sources of market intelligence, they influence firms' adaptation, as reflected in firms' new product introductions. We assert that a firm's board interlocks provide it with broad market intelligence on changing consumer preferences and emerging market trends, which stimulates the introduction of new products. As an illustration that firms introduce new products to adapt to new market intelligence, Olsen, Slotegraaf, and Chandukala (2014) find that firms responded to emerging market trends on environmental sustainability by introducing new environmentally friendly green products.

We note that incremental new products, even when introduced in response to the same broad market trend, are distinct from imitative new products (i.e., products that are introduced after a first innovator's product has been introduced in the market and use similar R\&D processes as the first innovator; Garcia and Calantone 2002). Whereas imitative products are generally, but not always, incremental in nature, not all incremental products are imitative products. ${ }^{2}$ From a theoretical perspective, we do not expect board interlocks to lead to imitation of other products in the category. It is unlikely that a firm's directors bring to board meetings descriptions of incremental new products introduced at other firms, which the firm can subsequently imitate. Moreover, as we subsequently report, an in-depth analysis of two product categories in our sample provided no evidence on the prevalence of imitative products in our context.

Furthermore, we note that the market intelligence drawn from the firm's board interlocks is unlikely to result in the introduction of breakthrough products. Specifically, drawing on the MOA framework, we expect that while market intelligence from board interlocks may give the focal firm an opportunity to respond with breakthrough products, developing such products is much more difficult than developing incremental products. Breakthrough products either involve new technology or offer high customer need fulfillment per dollar, or both (i.e., radical innovations per Chandy and Tellis [1998, p. 476]) and firms may not have the ability to create such products even when provided the opportunity. Developing incremental new products is easier and, thus, more likely.

In social network research, network centrality has been widely used to capture a firm's access to information in a social network (e.g., Gulati and Gargiulo 1999; Van den Bulte and Wuyts 2007). In the context of board interlocks and top management teams, network centrality has been used to capture a firm's information access (e.g., Wang, Gupta, and Grewal 2017; Westphal, Seidel, and Stewart 2001). It has been shown to affect

\footnotetext{
${ }^{2}$ We thank an anonymous reviewer for raising this issue.
} 
new product success (for an application in a social network of open source projects and developers, see Grewal, Lilien, and Mallapragada [2006]).

Integrating these ideas, we propose that a firm's central position in the board interlock network provides it with opportunities to leverage market intelligence by introducing new products. Applying the MOA theoretical framework (e.g., Tuggle et al. 2010; Wang, Gupta, and Grewal 2017), we further propose that leadership on the firm's board of directors will influence its motivation and ability to translate the market intelligence accessed from its board interlocks into new products. First, we propose that whether the firm is motivated and able to translate the opportunities from enhanced market intelligence into new products will be determined by the internal (vs. external) leadership profile of the board. Drawing on the corporate governance literature (Finkelstein and Hambrick 1990; Haynes and Hillman 2010), we distinguish between internal (i.e., board members who are executives of the firm) and external leadership (i.e., board members external to the firm, either from the same industry or from a different industry) on the board. Second, building on recent work on marketing leadership (e.g., Feng, Morgan, and Rego 2015; Germann, Ebbes, and Grewal 2015), we propose that marketing leadership on the firm's board will encourage the utilization of market intelligence obtained from its board interlocks, moderating the effect of its board interlock centrality on new product introductions. We consider the firm's marketing leadership because the marketing function differs from other functions (operations, finance, and accounting) in two respects. First, both market intelligence and new products are central to the marketing function. Thus, marketing leadership will be sensitive to consumers' needs (e.g., Kumar and Shah 2009; Paşa and Shugan 1996) and capable of influencing the firm's adaptation in response to these needs. Second, the marketing function is an output-based, "outside-in" function, whereas operations, finance, and accounting are throughput-based "inside-out" functions (Day 1994; Day and Moorman 2010). These unique qualifiers of the marketing function distinguish marketing leadership on the firm's board of directors as a potential moderator of the effect of board interlock centrality on new product introductions. We consider two aspects of marketing leadership on the board: internal marketing leadership (i.e., the presence of the firm's marketing executives on the board) and the marketing background of the CEO (i.e., whether the CEO has a marketing and/or sales background). Next, we discuss the main effect of the firm's board interlock centrality on new product introductions, followed by the moderating effects of internal (vs. external) leadership and marketing leadership on the board. We provide the conceptual framework in Figure 1.

\section{Main Effect of Board Interlock Centrality}

Because the flow of market intelligence across board interlocks is not directly observable, we focus on a construct closely

FIGURE 1

Conceptual Framework Relating Board Interlock Centrality to New Product Introductions

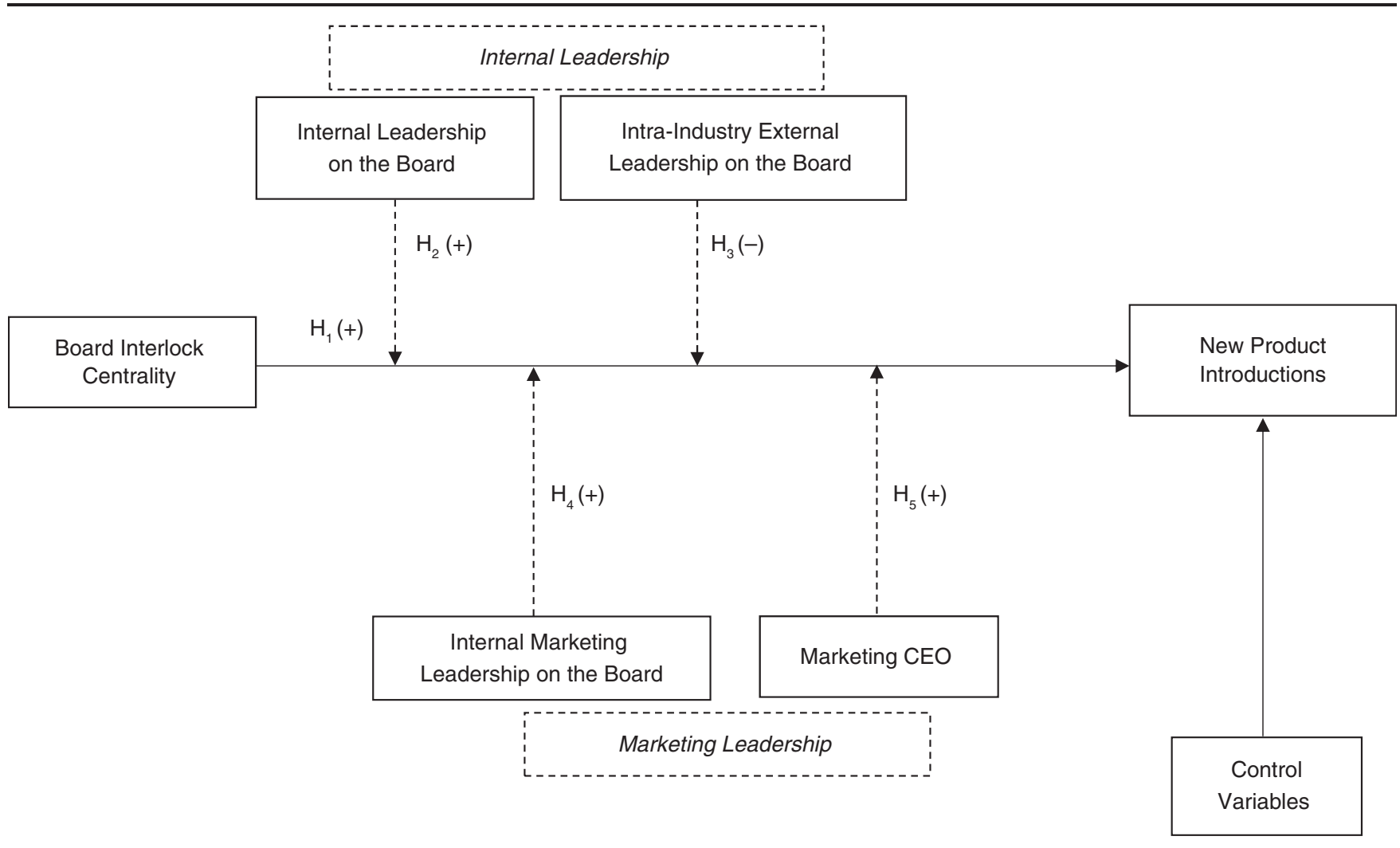

Notes: Although the main effects of the various moderators on new product introductions are included in the model that we estimate, we do not show them in the figure for ease of presentation. 
related to information access in a network setting: board interlock centrality. The more central the actor's position in a social network, the greater the actor's access to information from other actors in the network (Mizruchi 1996). By "access," we refer to direct access through an actor's direct ties to others (focal firm A shares an interlock tie with firm B) and indirect access through intermediary actors (focal firm $\mathrm{A}$ is indirectly connected with firm B, with a path distance of two, if both firms $A$ and $B$ share an interlock tie with a third firm $C$ ).

A more centrally connected firm in the board interlock network has greater exposure to information on the environment (i.e., market intelligence), including on changing consumer preferences and market trends (Beckman and Haunschild 2002; Wang, Gupta, and Grewal 2017). In line with research in marketing on market intelligence (Kohli and Jaworski 1990), we therefore expect that board interlock centrality serves as a source of opportunity for firms seeking to anticipate and address customer needs. Furthermore, new product introductions are known to be a key adaptation mechanism for leveraging market intelligence (e.g., Hendricks and Singhal 1997; Rindfleisch and Moorman 2001). Consequently, we anticipate that the firm's board interlock centrality will stimulate new product introductions. Thus, we propose $\mathrm{H}_{1}$ :

$\mathrm{H}_{1}$ : The higher the firm's board interlock centrality, the higher its new product introductions.

\section{Moderating Effects of Internal (vs. External) Leadership on the Board}

The market intelligence available to the firm's top management through the network connections of its board is filtered through its board of directors (Finkelstein and Hambrick 1990). Although a firm's board interlock centrality increases its access to market intelligence (Menon and Pfeffer 2003), it merely provides an opportunity for the firm to adapt by introducing new products (Rindfleisch and Moorman 2001). As noted previously, we further propose that whether the firm is motivated and able to translate opportunities arising from the received market intelligence into new products will depend on the internal (vs. external) leadership on the board.

We first consider the proportion of internal board members who are executives employed in the firm. Then, we consider the proportion of board members who are external directors from the same industry (intra-industry). We do not formulate a separate hypothesis for the third category, board members who are external directors from a different industry, because that proportion is a perfect linear combination of the preceding two proportions (i.e., they sum to one).

Internal leadership. We define internal leadership on a firm's board as the extent to which senior executives at the (focal) firm are also members of its board. Because the firm's senior executives are well-informed about its resources and constraints, they can more effectively generate consensus among senior management (Nyberg et al. 2010) than external leadership on the board. Moreover, because internal board members are knowledgeable about the firm's operations, they can develop feasible new product strategies (Finkelstein and Hambrick 1990) using market intelligence sourced from the firm's board interlocks. For example, when a firm becomes aware of emerging trends on environmental sustainability and the corresponding responses of other firms, it is able to use that information more effectively to introduce environmentally friendly products (as per Olsen, Slotegraaf, and Chandukala 2014) when the board consists of more internal (vs. external) board members. Furthermore, as the firm's senior managers, they are more invested in its performance because of incentive alignment through stock options (Jensen and Meckling 1976) and employment security. Thus, internal board members may be able to effectively leverage market intelligence sourced through board interlocks for the firm's benefit and be more motivated to do so because of self-interest in improving the firm's performance.

We note a potential counterargument: Internal directors may be susceptible to groupthink and resultant myopia (Janis 1972), which may cause them to deemphasize new market intelligence accessed through board interlocks. We expect, however, that internal directors' ability to interpret new market intelligence and incentive-aligned motivation to explore new opportunities to benefit the firm will outweigh this potential downside. Thus, overall, we anticipate that when internal leadership on the firm's board increases, market intelligence obtained from board interlocks may be more effectively leveraged (e.g., by adapting to emerging market trends), which should increase new product introductions. Thus, we propose $\mathrm{H}_{2}$ :

$\mathrm{H}_{2}$ : The positive effect of the firm's board interlock centrality on its new product introductions increases as the internal leadership on its board increases.

Intra-industry external leadership on the board. While external board members may bring in novel market intelligence from outside the firm, we propose two reasons why the benefits from market intelligence may be limited if the external board members are from other firms within the same industry (intraindustry) as compared with when they are from firms outside the industry. First, external board members have a fiduciary duty to the firm(s) on whose board(s) they serve (Tuggle et al. 2010). Thus, because intra-industry external directors have a fiduciary duty not only to the focal firm but also to other firm(s) in the industry in which they work and/or on whose boards they serve, they may be less motivated to share market intelligence. Although interlocked firms are unlikely to be direct competitors, as this is prohibited by law (Haunschild and Beckman 1998; Zajac 1988), firms within an industry may compete against each other in the future and/or may compete in an emerging market. For example, Eric Schmidt, an ex-CEO and board member at Google who was also a board member at Apple, resigned from Apple's board when Google started competing directly with Apple in the smartphone market. Therefore, even if the firms connected through board interlock(s) as a result of an intraindustry external director are currently not direct competitors, the director may not share market intelligence with potential competitive value because such sharing may violate his or her fiduciary duty to the other firm(s). External directors from firms in other industries do not face this issue: they will not face conflicting fiduciary duties because of competition.

Second, the firm's intra-industry external board members may also be less able to provide useful market intelligence, beyond what the firm already knows, because their industry experiences overlap with those of its senior management. 
Moreover, when a firm's board has more external directors from the same industry, it may be victim to groupthink and myopia (Janis 1972), limiting the market intelligence available from its board. Indeed, there is some evidence that a large knowledge domain overlap of actors in a network lowers awareness of alternatives, stifling, rather than stimulating, innovation (Rowley, Behrens, and Krackhardt 2000). In contrast, interorganizational linkages that provide access to different markets expand the focal firm's cognitive scope and help overcome myopia (Nooteboom 1992). Therefore, increasing the number of intra-industry external directors on the firm's board (at the expense of out-of-industry external directors) may weaken the effect of board interlock centrality on new product introductions.

In summary, as the proportion of intra-industry external leadership on a firm's board increases, it may reduce the firm's access to market intelligence through board interlocks as well as its novelty value. We note that, by construction, increasing intraindustry external leadership on the board occurs at the expense of out-of-industry external directors. Conversely, increasing the firm's proportion of out-of-industry external directors would help circumvent fiduciary duty concerns while effectively increasing the firm's cognitive scope. Thus, we expect that intraindustry external leadership on the firm's board will weaken the positive effect of its board interlock centrality on new product introductions, whereas out-of-industry external leadership will strengthen this effect. Thus, we propose $\mathrm{H}_{3}$ :

$\mathrm{H}_{3}$ : The positive effect of the firm's board interlock centrality on its new product introductions decreases as the firm's intraindustry external leadership on its board increases.

\section{Moderating Effects of Marketing Leadership on the Board}

Managers' functional backgrounds affect how they respond to information and how they incorporate that information into decision making and strategy formulation (Cho and Hambrick 2006; Ocasio 1997). Thus, the functional background of a firm's leadership will influence how market intelligence is used for decision making (e.g., Miller 1993; Prahalad and Bettis 1986). Adaptation through new products driven by market trends is a critical imperative for firms in industries in which new products are primarily incremental. In such industries, new product introductions become a key responsibility of the marketing function (Ettlie, Bridges, and O'Keefe 1984). Thus, we propose that marketing leadership on the firm's board will moderate the effect of its board interlock centrality on new product introductions.

Senior marketing executives are in a unique position to process market intelligence (Germann, Ebbes, and Grewal 2015; Kumar and Shah 2009) because they have the knowledge schemas needed to evaluate market intelligence and effectively incorporate it into marketing initiatives. Moreover, because marketing is an output (vs. throughput) function, marketing executives have an outside-in perspective as opposed to the inside-out perspective of executives from other functions (Day and Moorman 2010). Consequently, we propose that two aspects of marketing leadership on the firm's board, internal marketing leadership and the presence of a marketing CEO, will moderate the effect of board interlock centrality on new product introductions.
Internal marketing leadership. A high level of internal marketing leadership, which we define as the number of senior marketing executives from the firm on its board of directors, suggests that its marketing function is important in securing competitive advantage (Verhoef and Leeflang 2009). In a firm with high internal marketing leadership on the board, market intelligence obtained from its board interlocks is likely to be valued and swiftly acted on through new product introductions. Because marketing executives are in customer-facing roles, they may be better able to judge the quality and effectiveness of market intelligence discussed in board meetings (Perkins and Rao 1990). A high presence of internal marketing leadership on the board also signifies substantial relevant marketing expertise (Paşa and Shugan 1996) in the firm, which improves the firm's responsiveness to the market intelligence obtained from its board interlocks. These arguments are consistent with the idea that a firm's senior management creates the conditions needed to successfully convert market intelligence into marketing response design and implementation (Kohli and Jaworski 1990). Thus, we anticipate that as the internal marketing leadership on the firm's board increases, the effect of its board interlock centrality on its new product introductions will be higher. We propose $\mathrm{H}_{4}$ :

$\mathrm{H}_{4}$ : The positive effect of the firm's board interlock centrality on its new product introductions increases as the firm's internal marketing leadership on the board increases.

Marketing CEO. The functional background of the CEO is an indicator of the firm's relative emphasis on different functional areas in securing competitive advantage (Finkelstein and Hambrick 1990; Perkins and Rao 1990). The presence of a marketing CEO (i.e., one whose dominant functional background is in marketing) in a firm reflects the strong influence of marketing leadership on firm strategy and competitive advantage (Kirca, Jayachandran, and Bearden 2005)

Consistent with the arguments for the moderation effect of internal marketing leadership, when there is a marketing CEO, the firm's senior management, including the CEO, will be more aware of the growth and profit opportunities offered by new products. The managers of such a firm will be very motivated to leverage market intelligence from its board interlocks into new product introductions. This is facilitated by the external focus typical for firms that emphasize marketing as a source of competitive advantage (e.g., Homburg, Workman, and Krohmer 1999; Smith and White 1987). Thus, a firm with a marketing CEO will not only be motivated to respond to market intelligence, it will have the in-house skills and processes to achieve market adaptation through new product introductions. Thus, we propose $\mathrm{H}_{5}$ :

$\mathrm{H}_{5}$ : The positive effect of the firm's board interlock centrality on its new product introductions is greater when it has a marketing CEO.

\section{Method}

\section{Data}

We propose market intelligence sourced from the firm's board interlocks as the theoretical mechanism behind the effects of board interlocks on new, incremental product introductions. Thus, to test our hypotheses, we need an industry in which new 
products are primarily incremental in nature. As noted previously, nearly all new products in the CPG industry are incremental, in accordance with the categorization of innovations in extant research (Chandy and Tellis 1998, 2000).

We obtained information on the new product introductions of publicly listed food and beverage firms (which must report information on their boards of directors) in the CPG industry (Standard Industrial Classification codes beginning with 20) between 1997 and 2012 from the Product Launch Analytics database, which has been extensively used in previous research (e.g., Cao and Sorescu 2013; Gielens 2012; Olsen, Slotegraaf, and Chandukala 2014; Sorescu and Spanjol 2008; Ter Braak, Dekimpe, and Geyskens 2013; Wies and Moorman 2015). Food and beverage firms respond to changes in consumers' tastes and advances in health science (i.e., research on diets, carbs, and fats) by introducing new products, which are considered "the life force of food and beverages manufacturers" (Toops 2009). Focusing on food and beverage firms allows for an empirical test of the hypotheses, without potential confounds from interindustry variation. We list a representative set of products in Table A in the Web Appendix.

Over $97 \%$ of the new products of food and beverage firms are incremental innovations. Less than $3 \%$ of the new products entail new "technology" (most of which are incremental technological extensions, such as reformulations). ${ }^{3}$ Indeed, very few products qualify as radical innovations, characterized by high technological newness and high customer need fulfillment (Chandy and Tellis 1998). Furthermore, we note that an in-depth analysis of two product categories in our sample, yogurt and soups, provided no empirical evidence on the prevalence of imitative products in our context.

We collected information on firms' boards, CEOs, and board interlocks from the Corporate Board Member magazine's Director Database, firms' filings with the Securities and Exchange Commission (including their 10-K reports), Marquis "Who's Who" publications, and Dun \& Bradstreet's Reference Book of Corporate Managements. We collected information on various control variables including $\mathrm{R} \& \mathrm{D}$, sales and general administrative expenses (SG\&A), and revenues from Standard and Poor's Compustat database and collected patenting information from the United States Patent and Trademark Office database. We were able to obtain data on the key variables for 30 publicly listed firms that accounted for over US $\$ 420$ billion in revenues in 2012 , representing a substantial portion of the food and beverage market.

\section{Measures}

Dependent variable. The dependent variable is firms' annual count of new product introductions. The mean new product introductions per firm per year is $12.91(\mathrm{SD}=21.74)$.

Explanatory variables. Given our theoretical focus on the information role of board interlocks, we require a measure of the firm's centrality in the board interlock network that captures the total information flows to the firm through both its direct and

${ }^{3}$ Estimates are from the sample as per the Product Launch Analytics classification. indirect network connections. Direct connections between firms are represented through degree centrality, a count of firms in which the focal firm's board members are also board members of another firm (Bonacich and Lloyd 2001). Degree centrality, however, does not capture the firm's indirect information flows. For example, the firm has access to more information when the firms to which it is directly connected are also connected to many other firms. The centrality measure that captures the totality of all network connections is EVC (e.g., Grewal, Lilien, and Mallapragada 2006; Gulati and Gargiulo 1999), a weighted centrality of the firm in the interlock network in which the weights are the centralities of the other firms to which the focal firm is connected (Mariolis and Jones 1982; Mizruchi and Bunting 1981). Eigenvector centrality, which captures the direct and indirect connections of the firm to other well-connected firms (e.g., Owen-Smith and Powell 2004; Wasserman and Faust 1999) has been previously used to measure knowledge flows across firms (Haunschild and Beckman 1998; Wang, Gupta, and Grewal 2017), pertinent to our context.

We construct the board interlock network on the basis of a bimodal affiliation network (i.e., directors are affiliated with firms on whose boards they serve). In the board interlock network, two firms are connected through the directors who serve on the boards of both firms (Cohen, Frazzini, and Malloy 2012). We use this information to create an equivalent unimodal board interlock network between firms (e.g., Grewal, Lilien, and Mallapragada 2006) that shows the number of shared directors for each pair of firms. Using this network, we then calculate the EVC $c_{i}$ of a firm i connected to M(i) firms in a social network with a total of $\mathrm{N}$ firms as follows:

$$
c_{i}=\frac{1}{\lambda} \sum_{j \in M(i)} a_{i j} c_{j},
$$

where $a_{i j}=1$ if firms $i$ and $j$ are connected and 0 otherwise. Rewriting Equation 1 in eigenvector notation form gives us the following:

$$
\mathrm{Ac}=\lambda \mathrm{c},
$$

where $\mathrm{A}$ is the adjacency matrix showing the pattern of relationships between all firms in the network, $\lambda$ is the vector of eigenvalues, and $\mathrm{c}$ is the vector of centralities. Because Equation 2 can have multiple solutions for the eigenvalues, a constraint that only positive solutions are admissible (Bonacich and Lloyd 2001) results in the highest eigenvalue as the centrality score. Intuitively, the EVC of the focal firm is a weighted measure of its network centrality, with the weights being the centrality of the firms to which the focal firm is connected. Thus, firms connected to other more central firms have higher EVC.

We measure internal leadership on the firm's board (INRATIO) by the proportion of internal board members (i.e., the number of directors on the board who are executives at that focal firm divided by the size of the board; e.g., Bantel and Jackson 1989). ${ }^{4}$ We measure intra-industry external leadership

${ }^{4}$ We excluded the CEO in the measure of internal board members. We also considered a measure in which we included the CEO and verified that the results were robust. 
on the board (ININDRATIO) by the number of external board members who are from firms in the focal firm's industry, divided by the size of the board. We measure internal marketing leadership on the board (MKTRATIO) by the proportion of internal marketing board members (i.e., the number of directors on the board who are marketing executives at the focal firm [excluding the CEO, who may have a marketing background], divided by the size of the board).

To code the board members' functional backgrounds, we hired a graduate research assistant to read and categorize 100 randomly selected functional backgrounds. The assistant then developed a list of words to code each member's functional background. Then, we hired a second graduate research assistant to independently code the functional backgrounds; the two coders agreed on $84.6 \%$ of the cases. Next, we used the word list and conducted a content analysis using text analytics software on the profiles of all the board members in the database. The software categorized the members into functional backgrounds on the basis of the frequency of occurrence of keywords indicating a certain functional background. 5 We code the presence of a marketing CEO (MKTCEO) as a dichotomous variable based on whether the CEO's dominant experience in number of years was in the sales and/or marketing functions $(=1$, else $=0)$

\section{Control Variables}

To ensure correct model specification, we include the main effects of the four moderator variables as control variables. We also include as control variables the firm's $R \& D$ intensity (RDINT), measured as the ratio of R\&D expenditures to sales; patenting intensity (PATINT), measured as the log-transformed count of patents granted to the firm in a given year; and marketing intensity (MKTINT), measured as the ratio of SG\&A expenditures to sales.

We also control for CEO duality (CEODUAL; i.e., when the same person is the firm's CEO and chairman of its board) with a dummy variable (Galasso and Simcoe 2011; Tuggle et al. 2010). Because firms owned and controlled by families have authoritarian board structures that may affect their strategies (Kashmiri and Mahajan 2010; Smith and Amoako-Adu 1999), we control for it using a dummy variable (FAMILY). Finally, we control for the average size of the firms to which the focal firm is connected through its board interlocks, which we measure by their (log-transformed) sales (SIZEINTERLOCK). We list the measures and their data sources in Table 1. In Table 2, we report the descriptive statistics and the correlation matrix. Threat to validity from multicollinearity does not appear to be a concern because all variance inflation factors are below the recommended threshold of 10 (maximum variance inflation factor $=2.27$ )

\section{Model-Free Evidence}

In Table 3, we provide model-free evidence of the relationship between the firm's board interlock centrality and the annual count of its new product introductions. We split the sample into three groups in line with the 33rd and 67th percentile values of

5Details of this procedure are available from the authors on request. board interlock centrality. A one-way analysis of variance indicated that the mean number of new product introductions was statistically different across the groups $(\mathrm{F}(2,228)=7.98, p<$ $.01)$ and increased as the firm's board interlock centrality increased. Differences between paired groups were also statistically significant (low vs. medium: $\mathrm{t}=2.48, p<.02$; medium vs. high: $\mathrm{t}=3.45, p<.01$; low vs. high: $\mathrm{t}=3.96, p<.01$ ).

\section{Model Specification and Estimation}

We conducted several tests to ensure that the empirical specification is appropriate given the characteristics of the data. We used the Fisher test to verify the presence of unit roots in the dependent variable, an indication of stationarity. The test statistic rejected the omnibus null hypothesis that the data are generated by a first-order autoregressive process (Inverse $\chi_{62}^{2}=150.78, p<.01$ ). In addition, we found a modified Wald test for group-wise heteroskedasticity to be significant $\left(\chi_{28}^{2}=4,127.47, p<.01\right)$ indicating the presence of heteroskedasticity, which we addressed using clusterrobust standard errors in the estimation.

The dependent variable is the annual count of new product introductions of firm $i$ in year $t$. The mean of the dependent count variable was higher than $4(\mathrm{M}=12.91)$, and data were overdispersed $(\mathrm{SD}=21.74$, dispersion $=2.18$, range: $0-157)$. Therefore, we used a negative binomial regression approach, which accommodates count data with overdispersion. We observed zero introductions in only 42 firm-years (18\% of the sample).

To address potential endogeneity of board interlock centrality, we used a multipronged approach that included preestimation checks and an estimation approach that mitigated these concerns. First, we lagged board interlock centrality and other explanatory variables by one year to preclude reverse causality. Second, we included time dummies to account for regime-specific fluctuations in the dependent variable. Third, we used the two-step control function approach for estimation (Cameron and Trivedi 2013, p. 607), which has been used in recent marketing applications (e.g., Jindal and McAlister 2015; Sridhar et al. 2016). Following this approach, we first estimated an ordinary least squares regression with lagged board interlock centrality as the dependent variable, patenting intensity and R\&D intensity as exogenous variables, and firm and year dummies as explanatory variables. To satisfy the exclusion restriction, following recent empirical precedent (Germann, Ebbes, and Grewal 2015; Jindal and McAlister 2015), we included the average of board interlock centrality for all firms connected to the focal firm, excluding the focal firm. Conceptually, this variable is appealing because common industry norms on board member appointments are unlikely to be related to the error term. We then included the residuals from this first step as an explanatory variable in the new product introductions regression in the second step to provide the necessary correction for endogeneity.

Thus, we estimated a model that incorporates the main effect of board interlock centrality, the moderating (and related main) effects of the four board leadership variables, and the control variables. Following the standard negative binomial regression model (Dotzel, Shankar, and Berry 2013), the 
TABLE 1

Measures and Data Sources

\begin{tabular}{|c|c|c|}
\hline Variable & Measure & Data Sources \\
\hline $\begin{array}{l}\text { New product } \\
\text { introductions }\end{array}$ & $\begin{array}{l}\text { Number of new products introduced by the firm in } \\
\text { a given year }\end{array}$ & Product Launch Analytics \\
\hline $\begin{array}{l}\text { Board interlock } \\
\text { centrality }\end{array}$ & EVC of the firm in the board interlocks network & \multirow{5}{*}{$\begin{array}{l}\text { Firms' } 10-K \text { reports, Marquis Who's } \\
\text { Who publications, and Dun \& Bradstreet's } \\
\text { Reference Book and Directors Database }\end{array}$} \\
\hline $\begin{array}{l}\text { Internal leadership } \\
\text { on the board }\end{array}$ & $\begin{array}{l}\text { Ratio of the number of directors on the board who } \\
\text { are executives at the firm to the size of the board. }\end{array}$ & \\
\hline $\begin{array}{l}\text { Intra-industry external } \\
\text { leadership on the } \\
\text { board }\end{array}$ & $\begin{array}{l}\text { Ratio of the number of directors on the board who } \\
\text { are members at firms outside the firm but within } \\
\text { the industry to the size of the board. }\end{array}$ & \\
\hline $\begin{array}{l}\text { Internal marketing } \\
\text { leadership on the } \\
\text { board }\end{array}$ & $\begin{array}{l}\text { Ratio of the number of directors on the board who } \\
\text { are marketing executives in the firm to the size of } \\
\text { the board. }\end{array}$ & \\
\hline Marketing CEO & $\begin{array}{l}\text { Whether the CEO's dominant experience in terms } \\
\text { of number of years was in either the sales or } \\
\text { marketing functions }(=1 \text {, else }=0)\end{array}$ & \\
\hline $\begin{array}{l}\text { Control Variables } \\
\text { R\&D intensity }\end{array}$ & Ratio of firm's R\&D expenditure to firm sales & Compustat \\
\hline Patenting intensity & $\begin{array}{l}\text { Log-transformed number of patents granted to } \\
\text { the firm }\end{array}$ & $\begin{array}{l}\text { United State Patents and Trademarks } \\
\text { Office }\end{array}$ \\
\hline Marketing intensity & Ratio of firm's SG\&A expenditure to firm sales & Compustat \\
\hline CEO duality & $\begin{array}{l}\text { Whether the CEO is also the chairman of the } \\
\text { board }(=1 \text {, else }=0)\end{array}$ & $\begin{array}{l}\text { Firms' } 10-\mathrm{K} \text { reports, Marquis Who's Who } \\
\text { publications, and Dun \& Bradstreet's } \\
\text { Reference Book and Directors Database. }\end{array}$ \\
\hline Family ownership & $\begin{array}{l}\text { Whether the majority ownership was with a family } \\
(=1 \text {, else }=0)\end{array}$ & Firms' 10-K reports \\
\hline Size of interlocked firms & $\begin{array}{l}\text { Log-transformed average revenue of the firms } \\
\text { connected to the firm in the board interlock } \\
\text { network }\end{array}$ & Compustat \\
\hline
\end{tabular}

conditional mean of the dependent variable is specified as follows:

$$
\text { (3) } \begin{aligned}
\text { lny }_{\mathrm{i}, \mathrm{t}}= & \alpha_{\mathrm{i}}+\beta_{1} \text { EVC }_{\mathrm{i}, \mathrm{t}-1} \\
& +\beta_{2} \text { INRATIO }_{\mathrm{i}, \mathrm{t}-1}+\beta_{3} \text { ININDRATIO }_{\mathrm{i}, \mathrm{t}-1} \\
& +\beta_{4} \text { MKTRATIO }_{\mathrm{i}, \mathrm{t}-1}+\beta_{5} \text { MKTCEO }_{\mathrm{i}, \mathrm{t}-1} \\
& +\beta_{6}\left(\mathrm{EVC}_{\mathrm{i}, \mathrm{t}-1} \times \text { INRATIO }_{\mathrm{i}, \mathrm{t}-1}\right) \\
& +\beta_{7}\left(\mathrm{EVC}_{\mathrm{i}, \mathrm{t}-1} \times \text { ININDRATIO }_{\mathrm{i}, \mathrm{t}-1}\right) \\
& +\beta_{8}\left(\mathrm{EVC}_{\mathrm{i}, \mathrm{t}-1} \times \text { MKTRATIO }_{\mathrm{i}, \mathrm{t}-1}\right) \\
& +\beta_{9}\left(\mathrm{EVC}_{\mathrm{i}, \mathrm{t}-1} \times \text { MKTCEO }_{\mathrm{i}, \mathrm{t}-1}\right) \\
& +\beta_{10} \text { RDINT }_{\mathrm{i}, \mathrm{t}-1}+\beta_{11} \text { PATINT }_{\mathrm{i}, \mathrm{t}-1} \\
& +\beta_{12} \text { MKTINT }_{\mathrm{i}, \mathrm{t}-1}+\beta_{13} \text { CEODUAL }_{\mathrm{i}, \mathrm{t}-1} \\
& +\beta_{14} \text { FAMILY }_{\mathrm{i}, \mathrm{t}-1}+\beta_{15} \text { SIZEINTERLOCK }_{\mathrm{i}, \mathrm{t}-1} \\
& +\rho \omega_{\mathrm{i}, \mathrm{t}-1}+\tau \mathrm{D}_{\mathrm{i}, \mathrm{t}}+\varepsilon_{\mathrm{i}, \mathrm{t}},
\end{aligned}
$$

where $\beta_{1}-\beta_{15}$ are parameters specifying the impact of independent variables; $\rho$ captures the effect of $\omega_{i, t-1}$, the control function residuals from the board centrality regression; $\tau$ is a vector of unknown parameters specifying the impact of year dummies $D_{i, t} ; \alpha_{i}$ are firm-specific effects; and $\varepsilon_{i t}$ are firm-year specific errors. Furthermore, $\varepsilon_{i, t}=\ln \left(h_{i, t}\right)$, where $h_{i, t}$ follows a one-parameter gamma distribution $\mathrm{G}(\theta, \theta)$ with mean 1 and variance $\kappa=1 / \theta$.

\section{Results}

\section{Tests of Hypotheses}

We estimated three nested models: Model 1 (only the control variables, no theoretical variables; Bayesian information criterion $[\mathrm{BIC}]=1,545.688$ ) and Model 2 (control variables, including theoretical variables, no moderation effects; BIC = 1,533.446) are inferior to Model 3 (hypothesized model with all control variables; $\mathrm{BIC}=1,516.742$ ). We present the results of Model 3, which is appropriately specified for hypothesis testing, in Table 4.

We first report the tests of the hypotheses. We find support for $\mathrm{H}_{1}$, which posits a positive main effect of the firm's board interlock centrality on new product introductions $(\mathrm{b}=.020$, $p<.01)$.

We also find evidence that the effect of the firm's board interlock centrality on its new product introductions is moderated by leadership composition on the firm's board. The results support $\mathrm{H}_{2}$, that internal leadership on the firm's board 
TABLE 2

Descriptive Statistics and Correlation Matrix

\begin{tabular}{|c|c|c|c|c|c|c|c|c|c|c|c|c|c|}
\hline Variable & Mean & (SD) & 1 & 2 & 3 & 4 & 5 & 6 & 7 & 8 & 9 & 10 & 11 \\
\hline 1. Number of new product introductions & 12.91( & (21.73) & 1.00 & & & & & & & & & & \\
\hline 2. Board interlock centrality (EVC) & .14 & $(.23)$ & .22 & 1.00 & & & & & & & & & \\
\hline 3. Internal leadership on the board (INRATIO) & .27 & (.15) & -.29 & -.37 & 1.00 & & & & & & & & \\
\hline $\begin{array}{l}\text { 4. Intra-industry external leadership on the board } \\
\text { (ININDRATIO) }\end{array}$ & .15 & (.18) & -.01 & -.32 & .02 & 1.00 & & & & & & & \\
\hline $\begin{array}{l}\text { 5. Internal marketing leadership on the board } \\
\text { (MKTRATIO) }\end{array}$ & .15 & $(.16)$ & .29 & .08 & .10 & -.11 & 1.00 & & & & & & \\
\hline 6. Marketing CEO (MKTCEO) & .17 & $(.16)$ & 22 & .09 & .23 & .23 & .50 & 1.00 & & & & & \\
\hline 7. R\&D intensity (RDINT) & .003 & $(.005)$ & .24 & .01 & -.07 & .02 & .17 & .51 & 1.00 & & & & \\
\hline 8. Patenting intensity (PATINT) & 2.97 & (6.64) & .51 & .25 & -.30 & -.09 & .28 & .28 & .22 & 1.00 & & & \\
\hline 9. Marketing intensity (MKTINT) & .26 & $(.11)$ & .09 & .26 & -.12 & -.24 & .36 & .21 & .11 & .18 & 1.00 & & \\
\hline 10. CEO duality (CEODUAL) & .74 & $(.44)$ & .04 & .08 & -.01 & .05 & .09 & -.01 & .04 & -.05 & .03 & 1.00 & \\
\hline 11. Family owned (FAMILY) & .28 & $(.45)$ & -.04 & .06 & .04 & -.05 & -.06 & .04 & -.06 & -.01 & .07 & .07 & 1.00 \\
\hline $\begin{array}{l}\text { 12. Size of interlocked firms } \\
\text { (SIZEINTERLOCKED) }\end{array}$ & 8.58 & $(1.92)$ & .30 & .36 & -.52 & .07 & -.13 & .04 & .18 & .31 & -.07 & -.03 & .02 \\
\hline
\end{tabular}

Notes: Correlations over .12 are significant at $p<.05$.

strengthens the effect of board interlock centrality on new product introductions $(\mathrm{b}=.017, p<.01)$. In support of $\mathrm{H}_{3}$, intraindustry external leadership on the firm's board weakens the effect of board interlock centrality on new product introductions ( $\mathrm{b}=-.027, p<.01)$. In support of $\mathrm{H}_{4}$, internal marketing leadership on the firm's board strengthens the effect of board interlock centrality on new product introductions $(\mathrm{b}=.039, p<$ .01). Finally, we find support for $\mathrm{H}_{5}$, that a marketing $\mathrm{CEO}$ in the firm strengthens the effect of its board interlock centrality on new product introductions $(\mathrm{b}=.016, p<.01)$.

We next discuss the main effects of the moderators and control variables. Among the firm's board leadership variables, internal leadership has a negative effect $(b=-.934, p<.01)$, whereas internal marketing leadership $(\mathrm{b}=1.989, p<.01)$ and a marketing CEO $(b=.265, p<.10)$ in the firm have positive effects on new product introductions. Among firm-level controls, R\&D intensity $(\mathrm{b}=58.978, p<.01)$ and marketing intensity $(b=1.683, p<.05)$ have positive effects on new product introductions. ${ }^{6}$ Finally, the size of the interlocked firms has a positive and significant effect on new product introductions $(\mathrm{b}=.193, p<.01)$.

\section{Robustness Analyses}

Identification through an exogenous event. To establish the robustness of our two-step approach to account for potential endogeneity in board interlock centrality, we sought an alternative approach based on the occurrence of an exogenous event, which helps identify this causal effect under a quasiexperimental setting. We identified the Sarbanes-Oxley (SOX) Act as the exogenous event. The SOX Act required firms to have a majority of board members who are unaffiliated with the firm (i.e., more than $50 \%$ should be independent directors; Kay

${ }^{6}$ We note that we also estimated a model wherein we explicitly controlled for firm size. Because the correlation between sales and R\&D intensity was .65 and the results are unaffected by the inclusion of firm sales, for reasons of parsimony we report the model without firm size. and Vojtech 2015; New York Stock Exchange Listed Company Manual Section 303A.01). Firms that were noncompliant before the regulation was implemented were required to increase their number of external board members. Indeed, there is evidence that post-SOX, most firms did not change their board size but replaced their internal board members with outsiders to meet the $50 \%$ rule (e.g., Jiraporn, Singh, and Lee 2009; Kay and Vojtech 2015). Such a systematic change in board composition would influence board interlock centrality, which is a function of the number, as well as the position, of interlocked firms in the interlock network. It suffices that internal and external directors differ on any dimension related to external board memberships. Notably, we observe that internal directors are responsible for $42 \%$ of all interlocks, whereas external directors are responsible for only $26 \%$, which suggests that replacing internal directors with external directors may reduce firms' board interlock centrality. Furthermore, there is no reason to expect that the passage of the SOX Act would affect the random component of the outcome variable (the error term).

We compared the mean residuals of compliant and noncompliant firms and found no statistical difference between these groups, which supports the exogenous nature of the SOX

TABLE 3

Model Free Evidence: Main Effect of Board Interlock Centrality

\begin{tabular}{lc}
\hline $\begin{array}{l}\text { Level of Board } \\
\text { Interlock Centrality }\end{array}$ & $\begin{array}{c}\text { Annual Average New } \\
\text { Product Introductions }\end{array}$ \\
\hline Low & 8.00 \\
Medium & 11.65 \\
High & 18.49 \\
\hline Notes: Means statistically differ across groups: $\mathrm{F}(2,228)=7.98, p<$ \\
.01 . We used the 33rd and 67th percentiles for coding the low, \\
medium, and high levels of board interlock centrality. Differ- \\
ences between the groups were also significant (low and \\
medium: $\mathrm{t}=2.48, p<.02 ;$ medium and high: $\mathrm{t}=3.45, p<.01 ;$ low \\
and high: $\mathrm{t}=3.96, p<.01)$.
\end{tabular}


TABLE 4

Results from Estimation of Random Effects Negative Binomial Regression Models

\begin{tabular}{|c|c|c|c|c|c|c|c|}
\hline \multirow{2}{*}{$\begin{array}{l}\text { Variables } \\
\text { Board interlock centrality }\end{array}$} & \multirow{2}{*}{$\begin{array}{l}\text { Measures } \\
\text { EVC }\end{array}$} & \multirow{2}{*}{$\frac{\text { Hypothesis }}{\mathrm{H}_{1}}$} & Model 1 & \multicolumn{2}{|c|}{ Model 2} & \multicolumn{2}{|c|}{ Model 3} \\
\hline & & & - & $.018^{\star \star}$ & $(.01)$ & $.020^{\star \star}$ & $(.011)$ \\
\hline \multirow{4}{*}{$\begin{array}{l}\text { Moderation effects of } \\
\text { board leadership }\end{array}$} & EVC × INRATIO & $\mathrm{H}_{2}$ & - & - & & $.017^{\star \star \star}$ & $(.006)$ \\
\hline & EVC $\times$ ININDRATIO & $\mathrm{H}_{3}$ & - & - & & $-.027^{\star \star \star}$ & $(.009)$ \\
\hline & EVC × MKTRATIO & $\mathrm{H}_{4}$ & - & - & & $.039^{\star \star \star}$ & (.013) \\
\hline & EVC $\times$ MKTCEO & $\mathrm{H}_{5}$ & - & - & & $.016^{\star * \star}$ & $(.004)$ \\
\hline \multirow{4}{*}{$\begin{array}{l}\text { Main effects of board } \\
\text { leadership }\end{array}$} & INRATIO & & - & $-.673^{\star \star}$ & $(.401)$ & $-.934^{\star \star \star}$ & $(.453)$ \\
\hline & ININDRATIO & & - & .464 & $(.434)$ & .358 & (.447) \\
\hline & MKTRATIO & & - & $1.225^{\star \star}$ & $(.654)$ & $1.989^{\star \star \star}$ & (.718) \\
\hline & MKTCEO & & - & $.158^{\star}$ & $(.106)$ & $.265^{\star}$ & $(.201)$ \\
\hline \multirow[t]{5}{*}{ Focal firm characteristics } & RDINT & & $34.937^{\star \star}(20.241)$ & $42.729^{\star \star \star}$ & (21.610) & $58.978^{\star \star \star}$ & (20.033) \\
\hline & PATINT & & $.241^{\star \star \star} \quad(.100)$ & $.214^{\star \star \star}$ & $(.101)$ & $.227^{\star \star \star}$ & $(.095)$ \\
\hline & MKTINT & & $2.492^{\star \star \star} \quad(.911)$ & $1.432^{\star \star}$ & $(.924)$ & $1.683^{\star \star}$ & (1.005) \\
\hline & CEODUAL & & -.084 & -.133 & (.135) & -.061 & $(.126)$ \\
\hline & FAMILY & & $.035 \quad(.126)$ & .080 & $(.124)$ & .107 & $(.115)$ \\
\hline $\begin{array}{l}\text { Interlocked firms } \\
\text { characteristics }\end{array}$ & SIZEINTERLOCKED & & $.250^{\star \star *} \quad(.075)$ & $.265^{\star \star \star}$ & $(.088)$ & $.193^{\star \star \star}$ & (.086) \\
\hline Board centrality residuals & & & - & \multirow{2}{*}{\multicolumn{2}{|c|}{$-.002 \quad(.010)$}} & \multirow{2}{*}{\multicolumn{2}{|c|}{$\underset{\text { Included }}{-.002}$}} \\
\hline Time period dummies & & & Included & & & & \\
\hline Intercept & & & $-.339 \quad(.273)$ & -.951 & $(.788)$ & $-1.083^{\star}$ & $(.808)$ \\
\hline Sample size & & & 231 & 23 & & 23 & \\
\hline Log-likelihood & & & -710.256 & -690 . & 292 & -671 & 292 \\
\hline $\mathrm{BIC}$ & & & $1,545.688$ & 1,533 & 446 & 1,516 & 742 \\
\hline
\end{tabular}

${ }^{*} p<.10$.

${ }_{* \star}^{*} p<.05$

${ }^{* \star *} p<.01$.

Notes: Models 2 and 3 were estimated using a two-step approach as suggested by Cameron and Trivedi (2013, p. 607). Bootstrap standard errors are reported for Models 2 and 3 .

Act. Because the SOX Act is exogenous and affects board interlock centrality for noncompliant firms, it provides the necessary identification condition to rule out endogeneity in the effect of board interlock centrality on new product introductions. Because the SOX Act affects the proportion of the firm's internal board members and board interlock centrality, we created two groups: firms that met the SOX Act before it was enacted (and thus were not affected by it) and those that did not meet the 50\% rule in the SOX Act and had to change their board composition. We used a dummy variable to denote the period before and after the SOX Act (Kay and Vojtech 2015).

Next, we estimated a negative binomial regression model by including, in addition to the proposed variables, the dummy variable for regime change, the SOX Act; a dummy variable to capture whether the SOX Act affected the firm; and a three-way interaction term between the two dummies and the firm's board interlock centrality. A statistically significant interaction effect indicates that the change in the effect of the firm's board interlock centrality before and after the SOX Act differs between firms high versus low in internal leadership. Because the source of variation is related only to the SOX Act, the effect of board interlock centrality on new product introductions is uniquely identified by the significance of the three-way interaction term (for a similar application, see Andrews et al. 2015).

We present the results of this estimation in Model 4 in Table 5. For the readers' convenience, we also present results from the hypothesized Model 3 in Table 5. The three-way interaction effect is significant, ${ }^{7}$ which indicates that variation in new product introductions is significantly driven by exogenously induced variation in board interlock centrality. A comparison of the two models further indicates that the hypothesized effects are robust after accounting for the exogenous SOX Act.

Incremental nature of new products. We next report on an analysis that provides indirect evidence of the incremental nature of new products in the sample. Specifically, we recoded the variable internal-external directors to create a measure of out-of-industry external directors. We would, a priori, expect that out-of-industry external directors increase the effect of board interlock centrality on new product introductions for the reasons offered in $\mathrm{H}_{3}$. If, however, imitation is driving our results (and the dependent variable captures imitative products rather than, more generally, incremental new products), then out-of-industry external directors should decrease the effect of board interlock centrality rather than increase new product introductions. We find that the portion of out-of-industry directors increases the effect of board interlock centrality on new product introductions, supporting the developed theory and ruling out the alternative argument that imitation is driving new product introductions (results from this estimation are available from the authors on request).

\footnotetext{
${ }^{7}$ Its negative sign is consistent with our observation in the sample that internal directors create, on average, more interlocks ( $42 \%$ of all observed interlocks) than do external directors (26\%).
} 
Alternative estimators. We also estimated a model with unobserved instruments, based on the generalized method of moments, whereby identification is derived from restrictions on heteroskedastic covariance (see Lewbel [2012], p. 69). We report the results of this estimation in Model A1 in Table B in the Web Appendix. The results are generally consistent with our primary approach (Model 3 in Table 4). Furthermore, we estimated a negative binomial model using a fixed-effects estimator, the results of which are presented in Model A2 in Web Appendix Table B. Again, the results are consistent our main approach (Model 3 in Table 4).

Endogeneity of marketing leadership variables. Omitted variables may be a source of endogeneity of the marketing leadership variables, which could threaten the validity of the study's findings. We therefore conducted additional analyses correcting for potential endogeneity of the firm's marketing leadership using a control function approach (e.g., Sridhar et al. 2016). For internal marketing leadership, we use three instruments that satisfy the exclusion restriction, the focal firm's marketing intensity, the average internal marketing leadership ratio of its competitors, and market orientation (a measure that we developed using content analysis of firms' $10-\mathrm{K}$ statements, based on the word dictionary for market orientation developed by McKenny et al. 2016). We repeated this approach for the marketing CEO variable with the firm's marketing intensity and market orientation as instruments. The results (available on request) are robust to the inclusion of residuals from these first-stage regressions.

Marketing versus other functional backgrounds. Marketing is an outside-in function that sets it apart from inside-out functions such as finance, accounting, and operations. In addition, both the mechanism (market intelligence sourced from board interlocks) and the dependent variable (new product introductions) are central to the marketing function. Thus, we formulated moderation hypotheses only for marketing leadership. To explore whether other functions play a similar role, we estimated several alternative models. First, we created ratios of executives with alternative functional backgrounds on the board and estimated the model including the main effects of these ratios. We were able to estimate models only for the finance and accounting functions because the ratio for operations was highly correlated with the board's size, whereas we did not have sufficient observations for other functions (e.g., legal, R\&D). None of the main effects were statistically significant. Next, we added interaction effects between each functional ratio and board interlock centrality, one at a time. None of these interactions were statistically significant, underscoring the unique role of marketing leadership on the firm's board.

Sample. Finally, we verified whether the results are robust to the inclusion of firms from another CPG subindustry-namely, personal products firms. We collected data for these firms for the period 2007-2012, increasing the sample from 231 to 280 firmyear observations. This additional sample included firms such as Procter \& Gamble, Avon, Revlon, and Colgate-Palmolive, among others. (For estimates from this analysis, see Table $\mathrm{C}$ in the Web Appendix.) The results from this expanded sample are consistent with those obtained from the sample of only food and beverage firms. Overall, the various checks increase our confidence in the robustness of the relationship between board interlock centrality and new product introductions.

\section{Discussion}

Despite the growing recognition of a potential role for senior management in firms' innovation outcomes in managerial practice (Groysberg, Kelly, and MacDonald 2011), the role of firms' corporate boards, in general, and of their board interlock centrality, in particular, in innovation outcomes has been overlooked in the literature. Addressing this gap, we examine the effects of firms' board interlock centrality on new product introductions. Our findings demonstrate that firms do not benefit equally from the informational advantages offered by a central position in the board interlock network. Aspects of both internal (vs. external) leadership and marketing leadership on the board moderate the influence of board interlock centrality on new product introductions. Our findings provide novel insights on the top-down influence of board interlock centrality on new product introductions. We conclude with a discussion of the article's theoretical contributions, the managerial implications of the findings, and limitations and opportunities for future research.

\section{Theoretical Contributions}

We propose that a firm's central position in the board interlock network provides it with access to market intelligence, which, in turn, stimulates market adaptation and increases new product introductions. The positive main effect of a firm's board interlock centrality, measured by EVC, on new product introductions supports our argument. Furthermore, support for the moderation effects (internal leadership, intra-industry external leadership, internal marketing leadership, and a marketing CEO) indicates that a firm's board interlock centrality affects new product introductions differently on the basis of these leadership characteristics.

The moderation effects support the idea that whereas board interlock centrality provides access to market intelligence, the firm can better leverage this opportunity and translate the acquired market intelligence into more new product introductions when it has high internal leadership and lower intraindustry external leadership on its board. These findings are consistent with the MOA theoretical framework and with our rationale that board interlock centrality offers opportunities while board leadership characteristics influence the firm's ability and motivation to benefit from these opportunities and introduce new products. ${ }^{8}$ The findings also indicate that two marketing leadership characteristics of the firm, internal

${ }^{8} \mathrm{We}$ estimated a model to examine whether the firm's R\&D intensity mediates the relationship between the firm's board interlock centrality and its new product introduction rate. Board interlock centrality continues to have a significant direct effect on new product introductions in the presence of $\mathrm{R} \& \mathrm{D}$ intensity. We tested the indirect effect of board interlock centrality on new product introductions through R\&D intensity using a bootstrap analysis and found that the indirect effect was not significant $(b=.013,95 \%$ confidence interval $=-.047, .073$ ). This evidence confirms our central thesis that board interlock centrality affects new product introductions, via mechanisms other than R\&D intensity. 
TABLE 5

Alternative Model Using an Exogenous Event

\begin{tabular}{|c|c|c|c|}
\hline Variables & Measures & $\begin{array}{c}\text { Model 3: Proposed Model } \\
\text { Negative Binomial Regression }\end{array}$ & $\begin{array}{l}\text { Model 4: Negative Binomial } \\
\text { Regression Including } \\
\text { Exogenous Event }\end{array}$ \\
\hline Board interlock centrality & $\begin{array}{l}\text { EVC } \\
\text { EVC } \times \text { SOX } \times \\
\text { SOX_Affected }\end{array}$ & $.020^{\star *}-(.011)$ & $\begin{array}{rr}.018^{\star \star \star} & (.004) \\
-.421^{* \star} & (.158)\end{array}$ \\
\hline $\begin{array}{l}\text { Moderation effects of board } \\
\text { leadership }\end{array}$ & $\begin{array}{l}\text { EVC } \times \text { INRATIO } \\
\text { EVC } \times \text { ININDRATIO } \\
\text { EVC } \times \text { MKTRATIO } \\
E V C \times \text { MKTCEO }\end{array}$ & $\begin{array}{rr}.017^{\star \star \star} & (.006) \\
-.027^{\star \star \star} & (.009) \\
.039^{\star \star *} & (.013) \\
.016^{\star \star \star} & (.004)\end{array}$ & $\begin{array}{cc}.019^{\star *} & (.010) \\
-.013^{\star} & (.007) \\
.019^{\star} & (.013) \\
.011^{\star \star} & (.006)\end{array}$ \\
\hline $\begin{array}{l}\text { Main effects of board } \\
\text { leadership }\end{array}$ & $\begin{array}{l}\text { INRATIO } \\
\text { ININDRATIO } \\
\text { MKTRATIO } \\
\text { MKTCEO }\end{array}$ & $\begin{array}{cc}-.934^{\star * \star} & (.453) \\
.358 & (.447) \\
1.989^{\star \star \star} & (.718) \\
.265^{\star} & (.201)\end{array}$ & $\begin{array}{cc}-1.014^{\star * *} & (.509) \\
.049 & (.538) \\
2.381^{\star * *} & (.639) \\
.263^{*} & (.201)\end{array}$ \\
\hline Focal firm characteristics & $\begin{array}{l}\text { RDINT } \\
\text { PATINT } \\
\text { MKTINT } \\
\text { CEODUAL } \\
\text { FAMILY }\end{array}$ & $\begin{array}{cr}58.978^{\star * \star} & (20.033) \\
.227^{\star \star *} & (.095) \\
1.683^{\star *} & (1.005) \\
-.061 & (.126) \\
.107 & (.115)\end{array}$ & $\begin{array}{rr}32.100^{* *} & (15.485) \\
.003 & (.099) \\
.267 & (1.039) \\
-.014 & (.111) \\
.133 & (.119)\end{array}$ \\
\hline $\begin{array}{l}\text { Interlocked firms' } \\
\text { characteristics }\end{array}$ & SIZEINTERLOCKED & $.193^{\star * *} \quad(.086)$ & $.217^{\star * \star} \quad(.079)$ \\
\hline $\begin{array}{l}\text { Time period dummies } \\
\text { Intercept }\end{array}$ & & Included & Included \\
\hline $\begin{array}{l}\text { Sample size } \\
\text { Log-likelihood } \\
\text { BIC }\end{array}$ & & $\begin{array}{c}231 \\
-671.292 \\
1,516.742\end{array}$ & $\begin{array}{c}231 \\
-660.292 \\
1,521.95\end{array}$ \\
\hline
\end{tabular}

${ }^{*} p<.10$.

${ }^{\star *} p<.05$.

${ }^{\star * \star} p<.01$.

Notes: Model 4 also included the main effects of the SOX regime dummy variable and SOX_Affected dummies along with their two-way interactions with board interlock centrality.

marketing leadership and the presence of a marketing CEO, strengthen the positive effect of board interlock centrality on new product introductions.

This article's findings extend the nascent literature on topdown influences from the firm's senior leadership on organizational innovation (e.g., Rao, Chandy, and Prabhu 2008) and offer a novel, hitherto unexamined top-down driver of a firm's innovation outcomes: board interlock centrality. Furthermore, the findings highlight the critical role of senior marketing leadership on the firm's board and the CEO's marketing background in shaping strategy, adding to the body of knowledge on the crucial role of senior marketing leadership (e.g., Feng, Morgan, and Rego 2015; Germann, Ebbes, and Grewal 2015).

We also contribute to the emerging research on the role of social networks in marketing (Van den Bulte and Wuyts 2007), specifically in the innovation context. Over three decades ago, Granovetter (1985) noted that most social network studies suffer from the "problem of overembeddedness"- that is, a focus on network positions in explaining firms' behaviors. Social network research has overlooked heterogeneity among actors (e.g., ability and motivations to engage in actions enabled by their network positions). This "structuralist" perspective has conflated opportunity, ability, and motivation (e.g., Burt 1997). Only recently have network scholars questioned this dominant perspective and argued for a need to expand the theoretical terrain by distinguishing between the "opportunity" offered by a network position and actors' "motivation" (Obstfeld, Borgatti, and Davis 2014, p. 139), as we do in this research. Our analysis is not constrained to network positions; instead, we view network positions as merely providing an opportunity for action and include moderators that affect actors' motivation and ability.

Finally, while findings across diverse studies in the management literature have suggested that board interlocks affect many strategic behaviors (e.g., Haynes and Hillman 2010), prior research has not examined their effects on firms' innovation outputs. Thus, this article's findings — which suggest that board interlocks, in conjunction with board leadership characteristics, affect new product introductions - extend that literature in a novel way.

\section{Managerial Implications}

The study's findings also generate useful implications for business practice. First, the findings indicate that board interlocks emerge as bridges to valuable market intelligence, which is useful for developing innovations. Practitioners may consider formalizing the market intelligence obtained from board meetings (e.g., agenda setting and periodic review of information in board meetings) to leverage the board's role as a vehicle for improved information access to increase their innovation outputs. To examine whether new product introductions stabilize cash flows and reduce stock price volatility, we conducted additional analysis. We specified two models, both of which 
account for unobserved heterogeneity among firms and across time, with free cash flow and stock price volatility as the dependent variables (and the number of new product introductions as an explanatory variable). The findings indicate that, as we expected, new product introductions increase free cash flow $(p<.01)$ and decrease stock price volatility $(p<.05)$, reiterating the idea that new product introductions enhance shareholder value (Pauwels et al. 2004).

Second, the appointment of internal directors, out-ofindustry external directors, internal directors with marketing experience, and a marketing CEO all strengthen the positive impact of board interlock centrality on new product introductions, whereas a high proportion of intra-industry external directors weakens this effect. Firms in industries wherein product innovations are primarily incremental in nature can use our insights to increase their new product introductions. Furthermore, although we recognize that board appointments are also driven by many other governance considerations, our findings suggest that firms' C-suite executives must be cognizant of the differential effects on new product introductions, associated with external versus internal directors on the board and with marketing leadership versus other functional leadership on the board.

Third, we explore the economic relevance of our findings by estimating the marginal effect of board interlock centrality on new product introductions using the simulation-based approach of Krinsky and Robb (1986). Following this, we created two levels of each moderator (33rd and 67th percentile values) and estimated the value of the moderation effect at its 5th, 50th, and 95th percentile values in the simulated sample. The results, reported in Table 6, show that the magnitude of the effect in the simulated sample is consistent with our main findings.

Fourth, we also computed the marginal means of the dependent variable to assess the economic significance of the findings. Underscoring the managerial relevance of board interlock centrality, at the mean level of all covariates, a onestandard-deviation increase in a firm's board interlock centrality increases the number of new product introductions by $11 \%$. With respect to the moderators, at the mean level of all covariates, a one-standard-deviation increase in internal leadership and intra-industry external leadership on the board decreases new product introductions by $11 \%$ and $8 \%$, respectively. A one-standard-deviation increase in internal marketing leadership on the board increases new product introductions by $13 \%$, whereas a marketing CEO increases new product introductions by $15 \%$. Thus, the effects are economically substantive for business practice.

Note that whereas internal leadership positively moderates the effect of board interlock centrality on new product introductions, its negative main effect results in an overall negative effect, a decrease of $11 \%$. Perhaps the ill effects of groupthink directly and negatively influence new product introductions, which dominates any benefits from internal leadership on the board that would allow them to translate the market intelligence from board interlocks into new products.

\section{Limitations and Opportunities for Further Research}

We acknowledge a few shortcomings of our study, which provide opportunities for further research. First, as our empirical context, we chose food and beverage firms, in which new product introductions are driven primarily by changes in market trends and are predominantly incremental in nature, to avoid industry variation and to conduct a clean empirical test. We also showed that the results hold with an expanded sample that includes personal products firms. We expect that our results will generalize to contexts in which incremental new products are prevalent, such as mature competitive industries (Cao and Sorescu 2013, p. 955), but future research on other industries would be required to verify the generalizability of our findings.

Second, even though we ruled out on both theoretical and empirical grounds that product imitation may serve as an alternative mechanism, mimetic isomorphism may still be at work (DiMaggio and Powell 1983). Mimetic isomorphism refers to firms' standardized responses to uncertainty in the environment. Firms may develop a collective rationality and deploy similar strategies as they seek to address similar market trends. The consequences of mimetic isomorphism are an opportunity for future research. Furthermore, board interlocks may trigger more imitation in contexts other than incremental new products. Previous research has shown that board interlocks affect the diffusion of organizational practices such as "poison pills" (Davis 1991) and corporate acquisitions (Haunschild 1993), among others (e.g., Westphal, Seidel, and Stewart 2001). Future studies on whether such mimetic effects extend to marketing programs and practices (e.g., social

TABLE 6

Marginal Effect of Board Interlock Centrality on New Product Introductions

\begin{tabular}{lcc}
\hline & Low $\mathbf{5 \%}, \mathbf{5 0} \%, \mathbf{9 5} \%)$ & High $\mathbf{( 5 \% , 5 0 \% , 9 5 \% )}$ \\
\hline Internal leadership on the board & $.000, .002, .013$ & $.001, .006, .017$ \\
Intra-industry external leadership on the board & $.034, .025, .012$ & $.018, .014, .006$ \\
Internal marketing leadership on the board & $.001, .004, .014$ & $.000, .007, .017$ \\
\hline & Not Present & Present \\
\hline Marketing CEO & $.001, .012, .021$ & $.019, .035, .050$
\end{tabular}

Notes: We used the 33rd and 67th percentile values for creating the low and high levels of the moderator. We provide the 5th, 50th, and the 95th percentile values of the marginal effect based on the simulation draws. Because the variable marketing CEO is a categorical variable coded using a dummy variable, the marginal effects were calculated using the absence of the dummy as the baseline. 
media, channel design, the use of crowdsourcing) would be useful.

Third, following empirical precedent in the board interlocks literature, we used secondary data for our measures. Although secondary data have some advantages (e.g., no subjectivity bias), they preclude consideration of key organizational factors (e.g., firm culture) that may affect new product introductions. Future research relating firms' boards and board interlocks to new products using other methods (e.g., in-depth interviews, surveys of senior managers) across diverse industry contexts will be useful.

Fourth, we were not able to distinguish between interlocks created by internal versus external directors in our analysis. On average, $42 \%$ of firms' interlocks are created by internal directors who are not their CEO, $44 \%$ are created by the CEO, and $26 \%$ are created by their external directors. Thus, interlocks originate through different members on the board, which supports our argument that the board's centrality is critical to information transfer. Future research could differentiate between various sources of interlocks to extend these insights.

Finally, motivated by data availability on board interlocks, we considered only publicly listed firms. An interesting question for future research is whether and how board interlocks affect private firms and startups. Our research design also precludes consideration of industry characteristics (e.g., uncertainty) that affect new product introductions, which may be examined in future research.

In summary, we view our study as a useful first step in exploring the role of boards in the context of firms' marketing strategies, in general, and new product introductions, in particular. We hope that this research stimulates further work on the role of corporate board interlocks and marketing leadership in influencing firms' strategies and outcomes.

\section{REFERENCES}

Andrews, Michelle, Xueming Luo, Zheng Fang, and Anindya Ghose (2015), "Mobile Ad Effectiveness: Hyper-Contextual Targeting with Crowdedness," Marketing Science, 35 (2), 218-33.

Banbury, Catherine M., and Will Mitchell (1995), “The Effect of Introducing Important Incremental Innovations on Market Share and Business Survival," Strategic Management Journal, 16 (S1), 161-82.

Bantel, Karen A., and Susan E. Jackson (1989), “Top Management and Innovations in Banking: Does the Composition of the Top Team Make a Difference?" Strategic Management Journal, 10 (S1), 107-24.

Beckman, Christine M., and Pamela R. Haunschild (2002), "Network Learning: The Effects of Partners' Heterogeneity of Experience on Corporate Acquisitions," Administrative Science Quarterly, 47 (1), 92-124.

Bonacich, P., and P. Lloyd (2001), "Eigenvector-Like Measures of Centrality for Asymmetric Relations," Social Networks, 23 (3), 191-201.

Burt, Ronald S. (1997), "The Contingent Value of Social Capital," Administrative Science Quarterly, 42 (2), 339-65.

Cameron, Colin A., and Pravin K. Trivedi (2013), Regression Analysis of Count Data. Cambridge, UK: Cambridge University Press.

Cao, Zixia, and Alina Sorescu (2013), "Wedded Bliss or Tainted Love? Stock Market Reactions to the Introduction of Cobranded Products," Marketing Science, 32 (6), 939-59.

Carpenter, Mason A., and James D. Westphal (2001), "The Strategic Context of External Network Ties: Examining the Impact of Director Appointments on Board Involvement in Strategic Decision Making," Academy of Management Journal, 44 (4), 639-60.

Chandy, Rajesh K., and Gerard J. Tellis (1998), “Organizing for Radical Product Innovation: The Overlooked Role of Willingness to Cannibalize," Journal of Marketing Research, 35 (4), 474-87.

Chandy, Rajesh K., and Gerard J. Tellis (2000), "The Incumbent's Curse? Incumbency, Size, and Radical Product Innovation,' Journal of Marketing, 64 (3), 1-17.

Cho, Theresa S., and Donald C. Hambrick (2006), "Attention as the Mediator Between Top Management Team Characteristics and Strategic Change: The Case of Airline Deregulation," Organization Science, 17 (4), 453-69.
Cohen, Lauren, Andrea Frazzini, and Christopher J. Malloy (2012), "Hiring Cheerleaders: Board Appointments of 'Independent' Directors," Management Science, 58 (6), 1039-58.

Dalziel, Thomas, Richard J. Gentry, and Michael Bowerman (2011), "An Integrated Agency-Resource Dependence View of the Influence of Directors' Human and Relational Capital on Firms' R\&D Spending," Journal of Management Studies, 48 (6), $1217-42$.

Davis, Gerald F. (1991), “Agents Without Principles? The Spread of the Poison Pill Through the Intercorporate Network," Administrative Science Quarterly, 36 (4), 583-613.

Day, George S. (1994), "The Capabilities of Market-Driven Organizations," Journal of Marketing, 58 (4), 37-52.

Day, George, and Christine Moorman (2010), Strategy from the Outside In: Profiting from Customer Value. New York: McGraw Hill Professional.

DiMaggio, P., and W.W., Powell (1983), “The Iron Cage Revisited: Collective Rationality and Institutional Isomorphism in Organizational Fields," American Sociological Review, 48 (2), 147-60.

Dotzel, Thomas, Venkatesh Shankar, and Leonard L. Berry (2013), "Service Innovativeness and Firm Value," Journal of Marketing Research, 50 (2), 259-76.

Ettlie, John E., William P. Bridges, and Robert D. O'Keefe (1984), "Organization Strategy and Structural Differences for Radical Versus Incremental Innovation," Management Science, 30 (6), 682-95.

Feng, Hui, Neil A. Morgan, and Lopo L. Rego (2015), "Marketing Department Power and Firm Performance," Journal of Marketing, 79 (5), 1-20.

Finkelstein, Sydney, and Donald C. Hambrick (1990), “TopManagement-Team Tenure and Organizational Outcomes: The Moderating Role of Managerial Discretion," Administrative Science Quarterly, 35 (3), 484-503.

Galasso, Alberto, and Timothy S. Simcoe (2011), "CEO Overconfidence and Innovation," Management Science, 57 (8), 1469-84.

Garcia, Rosanna, and Roger Calantone (2002), "A Critical Look at Technological Innovation Typology and Innovativeness Terminology: A Literature Review," Journal of Product Innovation Management, 19 (2), 110-32.

Germann, Frank, Peter Ebbes, and Rajdeep Grewal (2015), "The Chief Marketing Officer Matters!" Journal of Marketing, 79 (3), $1-22$. 
Gielens, Katrijn (2012), "New Products: The Antidote to Private Label Growth?" Journal of Marketing Research, 49 (3), 408-23.

Granovetter, Mark S. (1985), "Economic Action and Social Structure: The Problem of Embeddedness," American Journal of Sociology, 91 (3), 481-510.

Grewal, Rajdeep, Gary L. Lilien, and Girish Mallapragada (2006), "Location, Location, Location: How Network Embeddedness Affects Project Success in Open Source Systems," Management Science, 52 (7), 1043-56.

Groysberg, Boris, Kevin L. Kelly, and Bryan MacDonald (2011), "The New Path to the C-Suite," Harvard Business Review, 89 (3), 60-68.

Gulati, Ranjay, and Martin Gargiulo (1999), "Where Do Interorganizational Networks Come From?" American Journal of Sociology, 104 (5), 1439-93.

Hambrick, Donald C. (2007), "Upper Echelons Theory: An Update," Academy of Management Review, 32 (2), 334-43.

Haunschild, Pamela R. (1993), "Interorganizational Imitation: The Impact of Interlocks on Corporate Acquisition Activity," $A d$ ministrative Science Quarterly, 38 (4), 564-92.

Haunschild, Pamela R., and Christine M. Beckman (1998), "When Do Interlocks Matter?: Alternate Sources of Information and Interlock Influence," Administrative Science Quarterly, 43 (4), 815-44.

Haynes, Katalin Takacs, and Amy Hillman (2010), "The Effect of Board Capital and CEO Power on Strategic Change," Strategic Management Journal, 31 (11), 1145-63.

Hendricks, Kevin B., and Vinod R. Singhal (1997), "Delays in New Product Introductions and the Market Value of the Firm: The Consequences of Being Late to the Market," Management Science, 43 (4), 422-36.

Homburg, Christian, John P. Workman Jr., and Harley Krohmer (1999), "Marketing's Influence Within the Firm," Journal of Marketing, 63 (2), 1-17.

Janis, Irving L. (1972), Victims of Groupthink: A Psychological Study of Foreign-Policy Decisions and Fiascoes. Boston: Houghton Mifflin.

Jensen, Michael C., and William H. Meckling (1976), "Theory of the Firm: Managerial Behavior, Agency Costs and Ownership Structure," Journal of Financial Economics, 3 (4), 305-60.

Jindal, Niket, and Leigh McAlister (2015), "The Impacts of Advertising Assets and R\&D Assets on Reducing Bankruptcy Risk," Marketing Science, 34 (4), 555-72.

Jiraporn, Pornsit, Manohar Singh, and Chun I. Lee (2009), "Ineffective Corporate Governance: Director Busyness and Board Committee Memberships," Journal of Banking \& Finance, 33 (5), 819-28.

Kashmiri, Saim, and Vijay Mahajan (2010), "What's in a Name? An Analysis of the Strategic Behavior of Family Firms," International Journal of Research in Marketing, 27 (3), 271-80.

Kay, Benjamin S., and Cindy M. Vojtech (2015), "Corporate Governance Responses to Director Rule Changes," Paper 20152, Office of Financial Research, https://www.financialresearch gov/staff-discussion-papers/files/OFRsdp2015-02_KayVojtechcorporate-governance-responses-to-director-rule-changes.pdf.

Kirca, Ahmet H., Satish Jayachandran, and William O. Bearden (2005), "Market Orientation: A Meta-Analytic Review and Assessment of Its Antecedents and Impact on Performance," Journal of Marketing, 69 (2), 24-41.

Kohli, Ajay K., and Bernard J. Jaworski (1990), "Market Orientation: The Construct, Research Propositions, and Managerial Implications," Journal of Marketing, 54 (2), 1-18.

Krinsky, Itzhak, and A. Leslie Robb (1986), "On Approximating the Statistical Properties of Elasticities," Review of Economics and Statistics, 68 (4), 715-19.

Kumar, V., and Denish Shah (2009), "Expanding the Role of Marketing: From Customer Equity to Market Capitalization," Journal of Marketing, 73 (6), 119-36.
Lamb, Nai H., and Philip Roundy (2016), "The 'Ties That Bind' Board Interlocks Research: A Systematic Review," Management Research Review, 39 (11), 1516-42.

Lang, James R., and Daniel E. Lockhart (1990), "Increased Environmental Uncertainty and Changes in Board Linkage Patterns," Academy of Management Journal, 33 (1), 106-28.

Lant, Theresa K., Frances J. Milliken, and Bipin Batra (1992), “The Role of Managerial Learning and Interpretation in Strategic Persistence and Reorientation: An Empirical Exploration," Strategic Management Journal, 13 (8), 585-608.

Lewbel, Arthur (2012), "Using Heteroscedasticity to Identify and Estimate Mismeasured and Endogenous Regressor Models," Journal of Business \& Economic Statistics, 30 (1), 67-80.

Lorsch, Jay W., and Elizabeth MacIver (1989), Pawns or Potentates: The Reality of America's Corporate Boards. Boston: Harvard Business School Press.

Mariolis, Peter, and Maria H. Jones (1982), "Centrality in Corporate Interlock Networks: Reliability and Stability," Administrative Science Quarterly, 27 (4), 571-85.

McKenny, Aaron F., Herman Aguinis, Jeremy C. Short, and Aaron H. Anglin (2016), "What Doesn't Get Measured Does Exist: Improving the Accuracy of Computer-Aided Text Analysis," Journal of Management, (published electronically July 14), DOI: 10.1177/0149206316657594.

Menon, Tanya, and Jeffrey Pfeffer (2003), "Valuing Internal vs. External Knowledge: Explaining the Preference for Outsiders," Management Science, 49 (4), 497-513.

Miller, Danny (1993), "The Architecture of Simplicity," Academy of Management Review, 18 (1), 116-38.

Mills, Wright C. (1956), The Power Elite. New York: Oxford University Press.

Mizruchi, Mark S. (1996), "What Do Interlocks Do? An Analysis, Critique, and Assessment of Research on Interlocking Directorates," Annual Review of Sociology, 22, 271-98.

Mizruchi, Mark S., and David Bunting (1981), "Influence in Corporate Networks: An Examination of Four Measures," Administrative Science Quarterly, 26 (3), 475-89.

Nguyen, Bang Dang (2012), "Does the Rolodex Matter? Corporate Elite's Small World and the Effectiveness of Boards of Directors," Management Science, 58 (2), 236-52.

Nooteboom, Bart (1992), "Towards a Dynamic Theory of Transactions," Journal of Evolutionary Economics, 2 (4), 281-99.

Nyberg, Anthony J., Ingrid Smithey Fulmer, Barry Gerhart, and Mason A. Carpenter (2010), "Agency Theory Revisited: CEO Return and Shareholder Interest Alignment," Academy of Management Journal, 53 (5), 1029-49.

Obstfeld, David, Stephen P. Borgatti, and Jason Davis (2014), "Brokerage as Process: Decoupling Third Party Action from Social Network Structure," in Contemporary Perspectives on Organizational Social Networks (Research in the Sociology of Organizations, Vol. 40, Daniel J. Brass, Giuseppe Labianca, Ajay Mehra, Daniel S. Halgin, and Stephen P. Borgatti, eds. Bingley, UK: Emerald Group Publishing Limited.

Ocasio, William (1997), "Towards an Attention-Based View of the Firm," Strategic Management Journal, 18 (Special Issue), 187-206.

Olsen, Mitchell C., Rebecca J. Slotegraaf, and Sandeep R. Chandukala (2014), "Green Claims and Message Frames: How Green New Products Change Brand Attitude," Journal of Marketing, 78 (5), 119-37.

Owen-Smith, Jason, and Walter W. Powell (2004), "Knowledge Networks as Channels and Conduits: The Effects of Spillovers in the Boston Biotechnology Community," Organization Science, 15 (1), 5-21. 
Palmer, Donald A., Devereaux P. Jennings, and Xueguang Zhou (1993), "Late Adoption of the Multidivisional Form by Large US Corporations: Institutional, Political, and Economic Accounts," Administrative Science Quarterly, 38 (1), 100-31.

Paşa, Mehmet, and Steven M. Shugan (1996), "The Value of Marketing Expertise," Management Science, 42 (3), 370-88.

Pauwels, Koen, Jorge Silva-Risso, Shuba Srinivasan, and Dominique M. Hanssens (2004), "New Products, Sales Promotions, and Firm Value: The Case of the Automobile Industry," Journal of Marketing, 68 (4), 142-56.

Perkins, W. Steven, and Ram C. Rao (1990), "The Role of Experience in Information Use and Decision Making by Marketing Managers," Journal of Marketing Research, 27 (1), 1-10.

Prahalad, Coimbatore K., and Richard A. Bettis (1986), "The Dominant Logic: A New Linkage Between Diversity and Performance," Strategic Management Journal, 7 (6), 485-501.

Rao, Raghunath Singh, Rajesh K. Chandy, and Jaideep C. Prabhu (2008), "The Fruits of Legitimacy: Why Some New Ventures Gain More from Innovation Than Others," Journal of Marketing, 72 (4), 58-75.

Rindfleisch, Aric, and Christine Moorman (2001), "The Acquisition and Utilization of Information in New Product Alliances: A Strength-of-Ties Perspective," Journal of Marketing, 65 (2), $1-18$.

Rowley, Tim, Dean Behrens, and David Krackhardt (2000), "Redundant Governance Structures: An Analysis of Structural and Relational Embeddedness in the Steel and Semiconductor Industries," Strategic Management Journal, 21 (3), 369-86.

Smith, Brian F., and Ben Amoako-Adu (1999), "Management Succession and Financial Performance of Family Controlled Firms," Journal of Corporate Finance, 5 (4), 341-68.

Smith, Mark, and Michael C. White (1987), "Strategy, CEO Specialization, and Succession," Administrative Science Quarterly, 32 (2), 263-80.

Sorescu, Alina B., and Jelena Spanjol (2008), “Innovation's Effect on Firm Value and Risk: Insights from Consumer Packaged Goods," Journal of Marketing, 72 (2), 114-32.

Sridhar, Shrihari, Frank Germann, Charles Kang, and Rajdeep Grewal (2016), "Relating Online, Regional, and National Advertising to Firm Value," Journal of Marketing, 80 (4), 39-55.

Steenkamp, Jan-Benedict E.M., and Katrijn Gielens (2003), "Consumer and Market Drivers of the Trial Probability of New Consumer Packaged Goods," Journal of Consumer Research, 30 (3), 368-84.
Ter Braak, Anne, Marnik G. Dekimpe, and Inge Geyskens (2013), "Retailer Private-Label Margins: The Role of Supplier and Quality-Tier Differentiation," Journal of Marketing, 77 (4), 86-103.

Toops, Diane (2009), “Top Selling New Food Products of 2008,' Food Processing (April 29), https://www.foodprocessing.com/ articles/2009/top-selling-food-products-of-2008/.

Tuggle, Christopher S., David G. Sirmon, Christopher R. Reutzel, and Leonard Bierman (2010), "Commanding Board of Director Attention: Investigating How Organizational Performance and CEO Duality Affect Board Members' Attention to Monitoring,' Strategic Management Journal, 31 (9), 946-68.

Useem, Michael (1984), The Inner Circle: Large Corporations and the Rise of Business Political Activity. New York: Oxford University Press.

Van den Bulte, Christophe, and Stefan Wuyts (2007), Social Networks and Marketing. Cambridge, MA: Marketing Science Institute.

Verhoef, Peter C., and Peter S.H. Leeflang (2009), "Understanding the Marketing Department's Influence Within the Firm,' Journal of Marketing, 73 (2), 14-37.

Wang, Rui, Aditya Gupta, and Rajdeep Grewal (2017), "Mobility of Top Marketing and Sales Executives in Business-to-Business Markets: A Social Network Perspective," Journal of Marketing Research, 54 (4), 650-70.

Wasserman, Stanley, and Katherine Faust (1999), Social Network Analysis: Methods and Applications. Cambridge, UK: Cambridge University Press.

Westphal, James D., and James W. Fredrickson (2001), "Who Directs Strategic Change? Director Experience, the Election of New CEOs, and Change in Corporate Strategy," Strategic Management Journal, 22 (12), 1113-37.

Westphal, James D., Marc-David L. Seidel, and Katherine J. Stewart (2001), "Second-Order Imitation: Uncovering Latent Effects of Board Network Ties," Administrative Science Quarterly, 46 (4), 717-47.

Wies, Simone, and Christine Moorman (2015), "Going Public: How Stock Market Listing Changes Firm Innovation Behavior," Journal of Marketing Research, 52 (5), 694-709.

Yadav, Manjit S., Jaideep C. Prabhu, and Rajesh K. Chandy (2007), "Managing the Future: CEO Attention and Innovation Outcomes," Journal of Marketing, 71 (4), 84-101.

Zajac, Edward J. (1988), "Interlocking Directorates as an Interorganizational Strategy: A Test of Critical Assumptions," Academy of Management Journal, 31 (2), 428-38. 


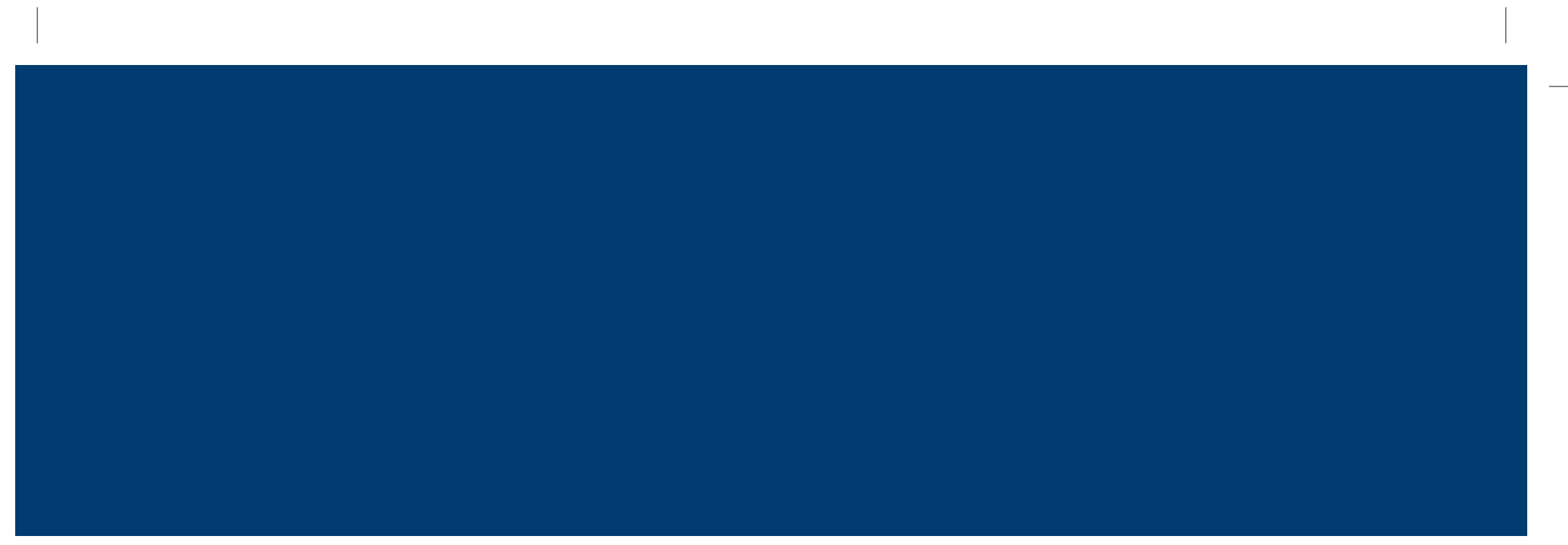


Copyright of Journal of Marketing is the property of American Marketing Association and its content may not be copied or emailed to multiple sites or posted to a listserv without the copyright holder's express written permission. However, users may print, download, or email articles for individual use. 